\title{
RATIONALE AND INSTITUTION FOR PUBLIC-PRIVATE PARTNERSHIPS
}

Jungwook Kim

NO. 557

September 2018
ADB ECONOMICS WORKING PAPER SERIES 
ADB Economics Working Paper Series

\section{Rationale and Institution for Public-Private Partnerships}

Jungwook Kim

No. 557 | September 2018
Jungwook Kim (awaker2@kdi.re.kr) is a Director of the Center for Regulatory Studies at the Korea Development Institute.

This paper has been prepared as background material for the Asian Development Outlook (ADO) 2017 Update theme chapter on Sustaining Development through Public-Private Partnership. 
(C) 2018 Asian Development Bank

6 ADB Avenue, Mandaluyong City, 1550 Metro Manila, Philippines

Tel +632632 4444; Fax +6326362444

www.adb.org

Some rights reserved. Published in 2018.

ISSN 2313-6537 (print), 2313-6545 (electronic)

Publication Stock No. WPS189536-2

DOI: http://dx.doi.org/10.22617/WPS189536-2

The views expressed in this publication are those of the authors and do not necessarily reflect the views and policies of the Asian Development Bank (ADB) or its Board of Governors or the governments they represent.

ADB does not guarantee the accuracy of the data included in this publication and accepts no responsibility for any consequence of their use. The mention of specific companies or products of manufacturers does not imply that they are endorsed or recommended by ADB in preference to others of a similar nature that are not mentioned.

By making any designation of or reference to a particular territory or geographic area, or by using the term "country" in this document, $A D B$ does not intend to make any judgments as to the legal or other status of any territory or area.

This work is available under the Creative Commons Attribution 3.0 IGO license (CC BY 3.0 IGO)

https://creativecommons.org/licenses/by/3.o/igo/. By using the content of this publication, you agree to be bound by the terms of this license. For attribution, translations, adaptations, and permissions, please read the provisions and terms of use at https://www.adb.org/terms-use\#openaccess.

This CC license does not apply to non-ADB copyright materials in this publication. If the material is attributed to another source, please contact the copyright owner or publisher of that source for permission to reproduce it. $\mathrm{ADB}$ cannot be held liable for any claims that arise as a result of your use of the material.

Please contact pubsmarketing@adb.org if you have questions or comments with respect to content, or if you wish to obtain copyright permission for your intended use that does not fall within these terms, or for permission to use the ADB logo.

Notes:

In this publication, “\$” refers to United States dollars.

ADB recognizes "Korea" as the Republic of Korea.

Corrigenda to ADB publications may be found at http://www.adb.org/publications/corrigenda. 


\section{CONTENTS}

TABLES, FIGURES, AND BOX iv

ABSTRACT V v

$\begin{array}{ll}\text { I. INTRODUCTION } & 1\end{array}$

II. THE EXPECTED ECONOMIC EFFECT OF INFRASTRUCTURE PUBLIC-PRIVATE
PARTNERSHIPS

III. EVIDENCE ON THE ECONOMIC EFFECTS OF PUBLIC-PRIVATE PARTNERSHIPS 3

A. Korea Development Institute Survey Results 3

B. Impact on Growth from Private Investment in Infrastructure 4

C. $\quad$ The Welfare Effect of Public-Private Partnership 6

D. Enhancing Value for Money through Public-Private Partnerships 6

E. Enhancing Efficiency by Reducing Time and Cost Overruns 8

IV. FINANCING PUBLIC-PRIVATE PARTNERSHIPS THROUGH THE CAPITAL MARKETS 8

V. UNSOLICITED PUBLIC-PRIVATE PARTNERSHIP PROJECT PROPOSALS

VI. GOVERNANCE ISSUES AFFECTING PUBLIC-PRIVATE PARTNERSHIP PROCESSES 12

A. Project Preparation $\quad 13$

B. Tendering and Contract Award 13

C. Operation and Management: Settling Public-Private Partnership Disputes 13

VII. LEGAL AND INSTITUTIONAL FRAMEWORKS FOR PUBLIC-PRIVATE PARTNERSHIPS 15

$\begin{array}{lll}\text { VIII. CONCLUSION } & 17\end{array}$

$\begin{array}{ll}\text { REFERENCES } & 19\end{array}$ 


\section{TABLES, FIGURES, AND BOX}

\section{TABLES}

12014 Survey on Build-Transfer-Operate Projects 3

2 Comparison Result on Characteristics of Build-Transfer-Lease Projects 4

3 Effect on Growth from Build-Transfer-Operate Projects in the Republic of Korea 5

$4 \quad$ Effect on Growth from Build-Transfer-Lease Projects in the Republic of Korea 5

$5 \quad$ Net Benefits from Public-Private Partnerships in the Republic of Korea, 2012

6 Value for Money Results for Public-Private Partnership Projects in the Republic of Korea 7

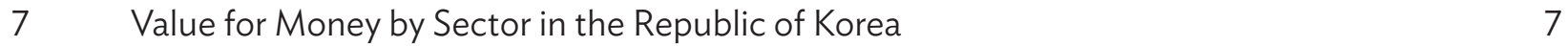

$8 \quad$ Estimated Value for Money for Public-Private Partnerships in the Republic of Korea 8

9 Infrastructure Bond Issuance in the Republic of Korea, 2009

10 Bond Issuance for Public-Private Partnership Projects in the Republic of Korea, 2012-2017 9

11 Unsolicited Proposals for Public-Private Partnerships Projects in Four Emerging Economies 11

12 Acceptance Ratio for Unsolicited Public-Private Partnerships in the Republic of Korea, 2009-2016

13 Average Dispute Resolution Periods for Public-Private Partnerships in the Republic of Korea, 2014

14 Dispute Resolution Processes 14

\section{FIGURES}

1 The Economic Contribution of Public-Private Partnerships 2

2 Major Governance Issues for Public-Private Partnerships 12

3 Performance of Public-Private Partnership Dispute Mediation in the Republic of Korea, 2012-2017 


\begin{abstract}
Private-public partnership (PPP) methods are considered to be an effective way to narrow the gap between demand and supply of social infrastructure. If successfully pursued, PPP can deliver benefits to users, governments, and the private sector, or the so-called triple wins. Enhancing efficiency by reducing cost and time overruns is beneficial to users and governments, and better quality of service is expected via PPP. It will also examine the factors that have been important for shaping the county's PPP landscape, including fiscal soundness, unsolicited project proposals, and the refinancing and renegotiation of PPPs.

PPPs are not a must-have solution but an option for building and upgrading infrastructure. In conclusion, PPPs are being promoted because it can mobilize needed resources from the private sector, maximize value for money, bring creativity and efficiency to a project, and be a source of fiscal stimulus. That said, countries should be clear on why they are promoting the PPP modality for infrastructure.
\end{abstract}

Keywords: economic growth, infrastructures, public-private partnership, value for money

JEL codes: E60, F62, H54, H81 


\section{INTRODUCTION}

The public-private partnership (PPP) modality can enhance the cost efficiency and quality of infrastructure, delivering benefits to the public, government, and private sector. Although these benefits are widely recognized, evidence is lacking on the actual contribution PPPs make to the economy. PPP projects can deliver significant economic benefits, but only if they are well executed, and strong legal, regulatory, and institutional frameworks are in place for these partnerships. This paper examines the economic effects of infrastructure PPPs in the Republic of Korea and, based on that experience, highlights some lessons learned for other countries in Asia looking to increase their use of PPPs to close infrastructure gaps.

The Republic of Korea started using the PPP modality as a response to a sharp decline in public and private investment in infrastructure in the late 1990s because of the Asian financial crisis, although its importance for closing infrastructure gaps was recognized earlier in that decade. The Public-Private Partnerships in Infrastructure Act of 1994 was revised in 1998 to strengthen risk-sharing mechanisms in PPP minimum revenue guarantees and construction subsidies, and to assign more infrastructure projects for these partnerships. Since 1998, the country has carried out more than 600 PPP projects.

This engagement with PPPs has by and large been a success and has contributed to delivering economic and social welfare benefits. A key reason for this is the country's strong legal, regulatory, and institutional frameworks to facilitate infrastructure PPP projects. This paper looks at how good governance and having clear options to resolve the disputes that are often inevitable in such partnerships have been to that process. The paper also examines the factors that have been important for shaping the county's PPP landscape, including fiscal soundness, unsolicited project proposals, and the refinancing and renegotiation of PPPs.

\section{THE EXPECTED ECONOMIC EFFECT OF INFRASTRUCTURE PUBLIC-PRIVATE PARTNERSHIPS}

PPPs are expected to have positive economic effects because they channel private resources into infrastructure spending. PPPs can ease budget constraints and help close demand-supply gaps for infrastructure-a pressing problem for many developing countries in Asia. All in all, PPPs are a good pathway for governments with limited fiscal resources to build more infrastructure. When well executed, infrastructure PPP projects have the same economic benefits as projects financed by traditional procurement in enhancing productivity and delivering social welfare benefits. PPPs are a way of allocating financial risk in the public and private sectors, and they can actively drive value for money and increase the efficiency of projects.

Even though private investment in infrastructure is increasing, it is not easy to gauge its contribution to economic growth. Using the World Bank's Private Participation in Infrastructure Database, Lee and Rhee (2007) show the relationship between PPP projects and economic growth. They find that infrastructure and total investment have positive impacts on economic growth, but that PPP infrastructure investments do not have a significant relationship with economic growth.

Using monthly time series data on the value of construction investment in the Republic of Korea, the authors find that an increase in PPP investment is associated with a decrease in public investment in both the short and long term, and only an increase in private investment in the short 
term. This indicates a crowding-out effect of PPPs on public investment. Even so, they conclude that this does not necessarily mean that PPPs have no role to play in providing infrastructure. Indeed, were it not for PPPs, infrastructure investment would have fallen significantly in the Republic of Korea during 2000-2006, the period covered in their study. Because PPPs were then at an early stage, a balanced evaluation of their impact on the economy had to wait until more projects were available for study.

Campos et al. (2003), studying macroeconomic variables in 21 Latin American countries during 1985-1998, found a negative correlation between infrastructure PPP projects and government spending on transport. The findings of this study and Lee and Rhee (2007) suggest that although PPPs may not have increased infrastructure investments, they contributed to maintaining these investments at a certain level. In the Republic of Korea, infrastructure investment would have fallen sharply had the government not promoted PPPs. Figure 1 shows the structural flow of the economic contribution of PPP projects.

The allocation of risk and improving service quality through a PPP can be achieved through higher value for money and efficiency. The Asian Development Bank (ADB) and Korea Development Institute (KDI) (2011) show that PPPs can have positive ripple effects on an economy by contributing to growth through private capital inputs, enhancing social welfare by the prompt delivery of services and the early realization of social benefits, and reducing fiscal burdens through better value for money. And when PPP's use advanced financial techniques they can contribute to developing financial markets.

Figure 1: The Economic Contribution of Public-Private Partnerships

\section{Public-private partnership projects}
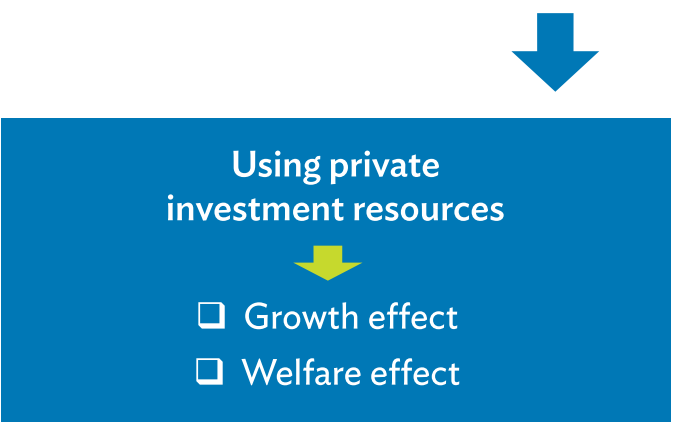

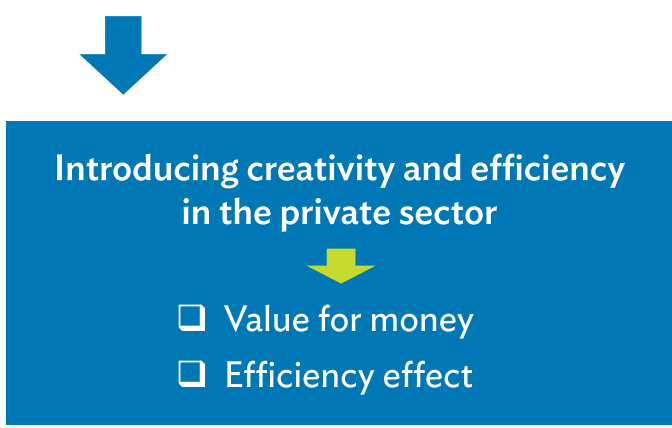

Source: Asian Development Bank and Korea Development Institute. 2011. Public-Private Partnership Infrastructure Projects: Case Studies from the Republic of Korea. Manila/Seoul. 


\section{EVIDENCE ON THE ECONOMIC EFFECTS OF PUBLIC-PRIVATE PARTNERSHIPS}

Many developing countries lack a solid body of empirical evidence on the economic effects of PPPs because not enough of these projects have been carried out to accumulate this evidence, a lack of resources, and inadequate data for this analysis. The Republic of Korea, however, has this evidence from surveys on the effects of various types of infrastructure PPPs, and these are presented in the following section.

\section{A. Korea Development Institute Survey Results}

In 2014, the KDI surveyed the quality of 16 build-transfer-operate (BTO) infrastructure projects, involving 57 respondents from government agencies, and operators (KDI 2014). ${ }^{1}$ Respondents rated the quality of these projects as being higher than similar government-funded projects, with PPPs scoring on governance, facility maintenance, and the early delivery of facilities, particularly for road and rail projects (Table 1). Creativeness and efficiency got the most positive responses, except for port construction. On the downside, $71 \%$ of respondents said service fees were too high for private finance initiative projects.

Table 1: 2014 Survey on Build-Transfer-Operate Projects

(\% of respondents)

\begin{tabular}{lccc}
\hline Sector & Prefer Public Project & No Preference & Prefer PPP Project \\
\hline Environment & 16.7 & 66.7 & 16.7 \\
Road & 0.0 & 50.0 & 50.0 \\
Rail & 0.0 & 87.5 & 12.5 \\
Harbor & 0.0 & 100.0 & 0.0 \\
\hline Total & 7.1 & 75.0 & 17.9 \\
\hline PPP = public-private partnership. & & \\
Note: The survey covered 16 build-transfer-operate projects and had 57 respondents. \\
Source: Korea Development Institute. 2014. Comprehensive Evaluation on Public-Private Partnership Projects in Korea. Sejong.
\end{tabular}

A KDI survey on 429 build-transfer-lease (BTL) infrastructure projects polled 54 government officials involved in these projects and operators, and 600 users of the finished infrastructure (KDI 2014). Respondents were asked whether they preferred PPPs to government-funded BTL projects. Most respondents said projects were built quicker using PPPs and that the expected benefits were achieved, especially for sewerage systems. Respondents also recognized the contribution of the creativeness and efficiency of the private partners. In the user survey, PPP project facilities were seen as better than government-funded ones (Table 2). Fifty-one percent of the respondents were satisfied with the level of fees for using PPP BTLs, and this satisfaction ratio rose to $70.7 \%$ for cultural and tourism facilities in certain areas. Most PPP facilities were evaluated as superior to government-funded facilities, with PPPs for military housing, cultural and tourism facilities, and schools scoring particularly highly. Noticeable features of PPP projects were diversity of facilities and well-constructed interiors.

1 The Korea Development Institute is the largest economic policy research institute in the Republic of Korea. 
4 | ADB Economics Working Paper Series No. 557

Table 2: Comparison Result on Characteristics of Build-Transfer-Lease Projects

\begin{tabular}{lccc}
\hline Criteria & Observations & Average & Standard Deviation \\
\hline Appearance & 598 & 2.159 & 1.182 \\
Convenience & 598 & 2.331 & 1.127 \\
Diversity of facilities & 597 & 2.437 & 1.136 \\
Function & 595 & 2.385 & 1.094 \\
Environment & 597 & 2.588 & 1.136 \\
Sanitary & 596 & 2.455 & 1.149 \\
Security & 596 & 2.622 & 1.133 \\
\hline
\end{tabular}

Note: Average response to a 6-point scale survey.

Source: Korea Development Institute. 2014. Comprehensive Evaluation on Public-Private Partnership Projects in Korea. Sejong.

In the survey of government officials and operators, respondents said infrastructure BTL projects using the PPP modality saved on construction time and achieved their targeted benefits. On the downside, respondents felt the Ministry of Strategy and Finance should improve its knowledge of laws applying to PPPs (31.5\% of respondents), and that operators needed to forge strong partnerships with the ministry, which oversees BTL projects (37\% of respondents). In sum, both surveys show that user satisfaction was greater for PPPs than government-funded infrastructure. But the results differed for type of facility. Overall, however, the results indicate that BOT and BTL infrastructure done through PPPs deliver higher quality services.

\section{B. Impact on Growth from Private Investment in Infrastructure}

Private investment in infrastructure in the Republic of Korea totaled W106 trillion ( $\$ 98.33$ billion) at the end of 2016 according to the Ministry of Strategy and Finance. Table 3 shows private investment in BTO infrastructure projects and its contribution to gross domestic product growth from 2001 to 2012. Table 4 shows the same for BTL projects from 2005 to 2012. 
Table 3: Effect on Growth from Build-Transfer-Operate Projects in the Republic of Korea (Won trillion)

\begin{tabular}{lccccc}
\hline Year & Nominal GDP & $\begin{array}{c}\text { Total Project Cost } \\
\text { of BTO Projects }\end{array}$ & $\begin{array}{c}\text { Private Investment } \\
\text { in BTO Projects }\end{array}$ & $\begin{array}{c}\text { Contribution } \\
\text { to GDP }\end{array}$ & $\begin{array}{c}\text { GDP Growth Effect } \\
(\%)\end{array}$ \\
\hline 2001 & 651.42 & 1.83 & 1.36 & 107 & 0.165 \\
2002 & 720.54 & 2.33 & 1.71 & 150 & 0.208 \\
2003 & 767.11 & 2.27 & 1.63 & 161 & 0.209 \\
2004 & 826.89 & 2.98 & 2.12 & 180 & 0.218 \\
2005 & 865.24 & 4.08 & 2.78 & 232 & 0.268 \\
2006 & 908.74 & 5.13 & 3.42 & 299 & 0.329 \\
2007 & 975.01 & 5.46 & 3.70 & 341 & 0.349 \\
2008 & $1,026.45$ & 5.86 & 4.10 & 381 & 0.371 \\
2009 & $1,065.04$ & 5.00 & 3.49 & 370 & 0.348 \\
2010 & $1,173.28$ & 3.36 & 2.47 & 291 & 0.248 \\
2011 & $1,235.16$ & 3.46 & 2.51 & 246 & 0.199 \\
2012 & $1,272.46$ & 3.53 & 2.72 & 249 & 0.195 \\
\hline
\end{tabular}

BTO = build-transfer-operate, $\mathrm{GDP}=$ gross domestic product.

Source: Korea Development Institute. 2014. Comprehensive Evaluation on Public-Private Partnership Projects in Korea. Sejong.

Table 4: Effect on Growth from Build-Transfer-Lease Projects in the Republic of Korea (Won trillion)

\begin{tabular}{lccccc}
\hline Year & Nominal GDP & $\begin{array}{c}\text { Total Project Cost } \\
\text { of BTLProjects }\end{array}$ & $\begin{array}{c}\text { Private Investment } \\
\text { in BTL Projects }\end{array}$ & $\begin{array}{c}\text { Contribution } \\
\text { to GDP }\end{array}$ & $\begin{array}{c}\text { GDP Growth Effect } \\
(\%)\end{array}$ \\
\hline 2005 & 865.24 & 0.0044 & 0.0044 & 0.15 & 0.00017 \\
2006 & 908.74 & 0.81 & 0.81 & 33 & 0.037 \\
2007 & 975.01 & 2.19 & 2.19 & 139 & 0.143 \\
2008 & $1,026.45$ & 3.58 & 3.56 & 276 & 0.269 \\
2009 & $1,065.04$ & 3.63 & 3.60 & 340 & 0.319 \\
2010 & $1,173.28$ & 3.88 & 3.85 & 364 & 0.310 \\
2011 & $1,235.16$ & 4.17 & 3.15 & 389 & 0.315 \\
2012 & $1,272.46$ & 3.77 & 3.77 & 384 & 0.302 \\
\hline
\end{tabular}

$\mathrm{BTL}=$ build-transfer-lease, GDP = gross domestic product.

Source: Korea Development Institute. 2014. Comprehensive Evaluation on Public-Private Partnership Projects in Korea. Sejong. 


\section{The Welfare Effect of Public-Private Partnerships}

Project evaluations of infrastructure PPPs in the Republic of Korea show they can bring social welfare benefits. ADB and KDI (2011) found the welfare benefits of 14 PPP road projects in the Republic of Korea were monetized 2 years earlier than publicly built roads by opening 2 years earlier. These projects produced social welfare benefits estimated at W1.46 trillion ( $\$ 1.33$ billion). Had these projects opened 1 year ahead of schedule, the welfare benefits would have been W623 billion ( $\$ 577.9$ million), W2.47 trillion ( $\$ 2.29$ billion) if opened 3 years ahead of schedule, and W3.3 trillion ( $\$ 3.02$ billion) if opened 4 years ahead of schedule. Assuming these projects were all completed in 2008 , the early realization of these welfare benefits is estimated at W1.85 trillion ( $\$ 1.69$ billion).

The welfare effects of infrastructure PPP projects can also be seen from the perspective of net benefits. In the Republic of Korea, formal feasibility studies are conducted on candidate PPP projects to assess, among other things, their potential welfare effects, which can be calculated as net benefits. Projects that cannot deliver sufficient welfare benefits are dropped. The net benefit of PPP projects that were underway in 2012, calculated in constant prices for that year, was W2.63 trillion (\$2.46 billion) (Table 5).

Table 5: Net Benefits from Public-Private Partnerships in the Republic of Korea, 2012

\begin{tabular}{lcccc}
\hline Sector & $\begin{array}{c}\text { Number of } \\
\text { Projects }\end{array}$ & $\begin{array}{c}\text { Total Benefit } \\
\text { (Won trillion) }\end{array}$ & $\begin{array}{c}\text { Total Cost } \\
\text { (Won trillion) }\end{array}$ & $\begin{array}{c}\text { Net Benefit } \\
\text { (Won trillion) }\end{array}$ \\
\hline Road & 18 & 8.79 & 6.36 & 2.42 \\
Environment & 9 & 1.37 & 1.18 & 0.19 \\
Culture & 2 & 0.72 & 0.62 & 0.10 \\
Rail & 2 & 2.97 & 3.04 & -0.07 \\
Others & 2 & 0.90 & 0.92 & -0.02 \\
\hline Total & 33 & 14.74 & 12.11 & 2.63 \\
\hline
\end{tabular}

Note: Total benefit is based on a feasibility study of a certain project and estimated as the cost savings or time savings from implementation of a certain project. Users' benefit from using the facility is one of the expected benefits.

Source: Korea Development Institute. 2014. Comprehensive Evaluation on Public-Private Partnership Projects in Korea. Sejong.

\section{Enhancing Value for Money through Public-Private Partnerships}

ADB and KDI (2011) show the results of several value-for-money tests for private financial initiatives from 66 BTO projects and 11 BTL projects during 2005-2012, valued at a combined W891 billion (\$815 million). Table 6 shows value-for-money tests for 72 PPP projects during 2005-2012, finding that $48 \%$ of the projects provided value for money-a total W2.64 trillion ( $\$ 2.42$ billion). ${ }^{2}$ Table 7 shows value for money by sector, with railways providing by far the most value. Table 8 gives the estimated value for money for private financial initiative projects.

2 The value for money is computed as a difference between expected fiscal burden from government-funded projects and expected fiscal burden from PPP project implementation. When value for money is positive, PPP implementation is preferred as it incurs less fiscal burden. 


\section{Table 6: Value for Money Results for Public-Private Partnership Projects in the Republic of Korea}

\begin{tabular}{lccc}
\hline Year & $\begin{array}{c}\text { Number of Tests } \\
\text { (BTL and BTO) }\end{array}$ & $\begin{array}{c}\text { Number of Projects with } \\
\text { Positive Value for Money }\end{array}$ & $\begin{array}{c}\text { Value for Money } \\
\text { (Won trillion) }\end{array}$ \\
\hline 2005 & 15 & 5 & 0.37 \\
2006 & 15 & 15 & 5.21 \\
2007 & 18 & 10 & 4.42 \\
2008 & 35 & 19 & 7.37 \\
2009 & 29 & 14 & 7.42 \\
2010 & 18 & 4 & 0.92 \\
2011 & 11 & 2 & 0.13 \\
2012 & 4 & 3 & 0.59 \\
\hline Total & 150 & 72 & 26.44 \\
\hline
\end{tabular}

$\mathrm{BTL}=$ build-transfer-lease, $\mathrm{BTO}=$ build-transfer-operate .

Source: Korea Development Institute. 2014. Comprehensive Evaluation on Public-Private Partnership Projects in Korea. Sejong.

Table 7: Value for Money by Sector in the Republic of Korea

\begin{tabular}{lccc}
\hline Sector & $\begin{array}{c}\text { Number of Tests } \\
\text { (BTL and BTO) }\end{array}$ & $\begin{array}{c}\text { Number of Projects with } \\
\text { Positive Value for Money }\end{array}$ & $\begin{array}{c}\text { Value for Money } \\
\text { (Won trillion) }\end{array}$ \\
\hline Rail & 22 & 11 & 13.26 \\
Road & 52 & 31 & 10.45 \\
Environment & 52 & 21 & 1.48 \\
Culture & 11 & 4 & 0.54 \\
Port & 2 & 1 & 0.53 \\
Others & 11 & 4 & 0.18 \\
\hline Total & 150 & 72 & 26.44 \\
\hline
\end{tabular}

$\mathrm{BTL}=$ build-transfer-lease, $\mathrm{BTO}=$ build-transfer-operate .

Source: Korea Development Institute. 2014. Comprehensive Evaluation on Public-Private Partnership Projects in Korea. Sejong. 
Table 8. Estimated Value for Money for Public-Private Partnerships in the Republic of Korea

\begin{tabular}{lccc}
\hline Item & Bumber of & $\begin{array}{c}\text { Value for Money } \\
\text { Projects }\end{array}$ & \begin{tabular}{c} 
(Won trillion) \\
\hline Ex ante VFM for PFI
\end{tabular} \\
& BTL & 66 & 0.89 \\
& Total & 96 & 0.09 \\
\hline Ex ante (additional) VFM for PFI Alternative & BTO & 66 & 1.55 \\
\hline Ex post (additional) VFM for PFI & BTO & 11 & 0.14 \\
& BTL & 84 & 0.17 \\
\cline { 2 - 4 } & Total & 95 & 0.31 \\
\hline
\end{tabular}

$\mathrm{BTL}$ = build-transfer-lease, $\mathrm{BTO}=$ build-transfer-operate, $\mathrm{PFI}$ = private finance initiative, $\mathrm{VFM}$ = value for money.

Source: Asian Development Bank and Korea Development Institute. 2011. Case Studies from Korea on Public-Private Partnership Infrastructure Project. Manila/Seoul.

\section{E. Enhancing Efficiency by Reducing Time and Cost Overruns}

Infrastructure PPP projects can score on cost and time efficiency over traditionally procured projects. PPP infrastructure projects in some advanced economies have shown they can reduce cost and time overruns compared with government-funded projects. McDonald (2002) found that traditional public procurement projects suffered cost overruns of $24 \%-66 \%$ and time overruns of $4 \%-39 \%$ during construction in the United Kingdom, but PPP projects were more efficient in both. In his sample, 78\% of PPP projects were within budget, compared with $27 \%$ of government-funded projects.

\section{FINANCING PUBLIC-PRIVATE PARTNERSHIPS THROUGH THE CAPITAL MARKETS}

Several Asian countries including the Republic of Korea, Malaysia, and Thailand have well-developed domestic capital markets, and were early users of infrastructure and corporate bonds, and listed equities, for financing PPPs in the region. Overall, however, considerable differences exist in the depth, liquidity, and structure of capital markets among Asian countries. This section examines how the Republic of Korea has financed PPPs in the capital market.

Infrastructure bonds were not much used in the Republic of Korea during the early phase of PPPs. Out of 203 BTO projects implemented by 2009, only seven were partly financed by these bonds (Table 9). One reason for their low use is the country's practice of funding infrastructure projects in a sequence, corresponding to the progress of construction and future equity sales. Table 10 shows infrastructure bond issuance for PPPs during 2012-2017 when 18 bonds were issued, totaling W3 trillion ( $\$ 2.81$ billion). This occupies a significantly high $21.7 \%$ of the combined cost of the 18 projects, an indication of the financial market's recognition of the characteristics of PPP projects, such as profitability and riskiness. This clearly shows that the depth and sophistication of financial markets can affect the implementation of PPPs. 
Table 9: Infrastructure Bond Issuance in the Republic of Korea, 2009

\begin{tabular}{lcccr}
\hline & \multicolumn{3}{c}{ Sector } & Total \\
\cline { 2 - 4 } & Airport & Road & Rail & 7 \\
Number of projects & 2 & 3 & 2 & 3.377 \\
Amount of bond issuance (Won billion) & 0.147 & 1.630 & 1.600 & $\ldots$ \\
Amount of issuance/Total project cost (\%) & 74.75 & 35.06 & 35.23 & \\
\hline
\end{tabular}

... = not available

Source: Asian Development Bank and Korea Development Institute. 2010. Case Studies from Korea on Public-Private Partnership Infrastructure Project. Manila.

Table 10: Bond Issuance for Public-Private Partnership Projects in the Republic of Korea, 2012-2017

\begin{tabular}{|c|c|c|c|c|c|}
\hline Project Type & Amount (A) & Issue Date & Interest Rate & $\begin{array}{c}\text { Total Project } \\
\text { Cost (B) }\end{array}$ & $A / B$ \\
\hline Road & 0.13 & Jun 2012 & 4.85 & 0.48 & 27.20 \\
\hline Road & 0.12 & Jul 2013 & 4.25 & 0.48 & 24.87 \\
\hline Road & 0.06 & Nov 2013 & 4.10 & 0.20 & 29.59 \\
\hline Road & 0.30 & Oct 2013 & 4.03 & 0.86 & 34.84 \\
\hline Rail & 0.18 & Jun 2014 & 4.30 & 0.96 & 18.62 \\
\hline Environment & 0.02 & Jul 2015 & 3.50 & 0.08 & 31.17 \\
\hline Road & 0.30 & Jul 2015 & 3.33 & 2.27 & 13.21 \\
\hline Road & 0.11 & Nov 2015 & 3.39 & 0.15 & 72.88 \\
\hline Road & 0.10 & Dec 2015 & 3.60 & 1.33 & 7.52 \\
\hline Logistics & 0.09 & Jan 2016 & 3.40 & 0.16 & 56.38 \\
\hline Rail & 0.40 & Apr 2017 & 3.10 & 1.40 & 28.49 \\
\hline Rail & 0.40 & Apr 2017 & 2.77 & 1.04 & 38.42 \\
\hline Road & 0.27 & Apr 2017 & 3.20 & 0.51 & 52.78 \\
\hline Rail & 0.15 & Apr 2017 & 3.30 & 0.87 & 17.23 \\
\hline Road & 0.14 & May 2017 & 3.31 & 0.20 & 66.59 \\
\hline Sports center & 0.02 & Jun 2017 & 3.72 & 0.03 & 74.13 \\
\hline Road & 0.14 & Aug 2017 & 3.90 & 1.89 & 7.40 \\
\hline Road & 0.10 & Sep 2017 & 3.00 & 1.04 & 9.62 \\
\hline
\end{tabular}

Source: Public and Private Infrastructure Investment Management Center. 
While it is true that PPP projects enable governments to implement social infrastructure projects despite limited financial resources, it is neither possible nor recommended to rely entirely on PPPs for infrastructure. When governments borrow to finance infrastructure through PPPs, these loans need to be paid off in the medium and long term, and governments cannot increase the amount of future liability indefinitely. Insufficient government financial resources, which often happen because of past heavy investment, can lead to a drop in public spending on infrastructure, which in turn can hurt gross domestic product growth and affect a government's ability to repay debt. Because of infrastructure's effect on growth, many developing countries in Asia are promoting PPPs rather than cutting infrastructure spending when financial resources are tight.

Indeed, the increased interest in PPPs for building and upgrading infrastructure puts a spotlight on the need for clear budgeting and accounting rules for PPP projects (see Box below). However, standards are lacking. And because of this, PPPs can be used to circumvent safety ceilings and fiscal rules on spending, thereby creating an incentive to move public investments off government balance sheets. This could include allocating spending to future budgets, thereby increasing government liabilities, and providing guarantees for private financing. Regardless of how this is done, taxpayers bear the risk of high liability in the future from these practices. Governments therefore need to incorporate procedures in their budgeting systems to deal with these risks as they apply to PPP projects. There is no one-size-fits-all procedure for this, and procedures will need to be calibrated to specific country requirements. But governments everywhere should continuously update their national budgeting systems to ensure affordability, value for money, and long-term fiscal sustainability. They should also develop the process of connecting accounting and budget rules that affect the choice of mode of service delivery and procurement options based on value for money.

\section{Box: Accounting Standards for Public-Private Partnerships}

Governments promote infrastructure public-private partnership (PPP) projects because they lack the resources to carry out these projects themselves, and to benefit from the creativity and efficiency of the private sector. But to what extent should PPPs replace government-funded infrastructure investments? The answer is that in using this modality, governments must maintain fiscal stability.

This is one reason why it is important to have comprehensive accounting standards for treating PPPs in national budgets and to have comparable international statistics. But these are lacking everywhere. Even developed countries and regions, such as the European Union, do not have clear accounting standards on PPPs.

The view of Eurostat, which provides statistical information to European Union institutions, is that PPP assets should be classified outside the government sector if both of the following conditions are met: the private partner bears the construction risk and either the availability or demand risk.

The party carrying the risk, however, is not always easy to define because types of contract design vary. In many cases, it is not possible to classify a PPP as being on or off government books. Eurostat research, in collaboration with the European PPP Expertise Centre and the European Investment Bank, highlights the need for revising these criteria to conform to international public sector accounting standards (Eurostat 2009). Within the accounting profession, efforts are underway to give guidance on comprehensive standards for this, but more is needed.

Source: Kim, Jay-Hyung, Jungwook Kim, Sunghwan Shin, Seung-Yeon Lee. 2011. Public-Private Partnership Infrastructure Projects: Case Studies from the Republic of Korea. Seoul: KDI. 


\section{UNSOLICITED PUBLIC-PRIVATE PARTNERSHIP PROJECT PROPOSALS}

Unsolicited projects are widely used in emerging economies, with the Republic of Korea having one of the world's highest ratios of solicited to unsolicited projects. As of March 2015, 54.1\% of 222 BTO projects started out as unsolicited project proposals, accounting for $58.2 \%$ of total investment in BTO projects. Table 11 shows the extent of the use of unsolicited project proposals in four emerging economies: Chile; the Republic of Korea; South Africa; and Taipei,China.

Table 11: Unsolicited Proposals for Public-Private Partnerships Projects in Four Emerging Economies

\begin{tabular}{llcccc}
\hline & \multicolumn{1}{c}{ Period } & $\begin{array}{c}\text { Presented } \\
\text { Economy }\end{array}$ & $\begin{array}{c}\text { Accepted } \\
(\mathrm{B})\end{array}$ & $\begin{array}{c}\text { Under } \\
\text { Review } \\
\text { (C) }\end{array}$ & $\begin{array}{c}\text { Acceptance } \\
\text { Ratio } \\
\left(\frac{\mathrm{B}}{\mathrm{A}-\mathrm{C}}\right)\end{array}$ \\
\hline Chile & March 1995 to December 2006 & $200+$ & 26 & 38 & $\leq 0.160$ \\
Korea, Rep. of & July 1999 to April 2006 & 141 & 101 & 7 & 0.754 \\
South Africa & 1999-2006 & 4 & 0 & 3 & 0 \\
Taipei,China & March 2002 to May 2006 & 193 & 29 & 22 & 0.170 \\
\hline
\end{tabular}

Source: Hodges, John T., and Georgina Dellacha. 2007. "Unsolicited Infrastructure Proposals: How Some Countries Introduce Competition and Transparency." PPIAF Working Paper No. 1. Nairobi: Public-Private Infrastructure Advisory Facility; and authors' calculation.

Flexible and inventive project approaches are a positive side to unsolicited project proposals, and they impose less of a financial burden on ministries. Lower priority projects tend to be put forward as unsolicited proposals, as there might be fewer financial incentives for the private sector alone to implement them. Given this, governments should evaluate the importance of unsolicited proposals in terms of their national plans and priority.

Because solicited projects take considerable time and costs to push through, unsolicited PPP proposals have been actively sought by the government in the Republic of Korea. The government, however, is putting more effort into solicited projects because they align better to the country's national economic plan and its priorities for infrastructure. Table 12 shows the acceptance ratios for unsolicited PPP project proposals from 2009 to 2016. Value-for-money tests and competitive bidding processes are applied to unsolicited projects proposals, and this has resulted in getting value for money from unsolicited project proposals. In this way, the government tries to secure efficiency and fiscal soundness in PPP for unsolicited projects.

The expectation that new PPP projects will continually come on stream has helped maintain private sector interest in infrastructure projects and programs in the Republic of Korea. Even so, the government still lacks the technical and financial capacity to manage projects that started out as unsolicited proposals. Because these projects can encourage innovation in the private sector, the lesson for developing Asia from the Republic of Korea's experience in dealing with unsolicited project proposals is that countries need to build this capacity in their agencies working on PPPs. 
Table 12: Acceptance Ratio for Unsolicited Public-Private Partnerships in the Republic of Korea, 2009-2016

\begin{tabular}{lcccc}
\hline Year & $\begin{array}{c}\text { Presented } \\
(A)\end{array}$ & $\begin{array}{c}\text { Accepted } \\
(B)\end{array}$ & $\begin{array}{c}\text { Under Review } \\
(C)\end{array}$ & $\begin{array}{c}\text { Acceptance Ratio } \\
\left(\frac{\mathrm{B}}{\mathrm{A}-\mathrm{C}}\right)\end{array}$ \\
\hline 2009 & 35 & 13 & 0 & 0.371 \\
2010 & 18 & 6 & 0 & 0.330 \\
2011 & 15 & 5 & 0 & 0.330 \\
2012 & 14 & 5 & 0 & 0.357 \\
2013 & 19 & 6 & 0 & 0.316 \\
2014 & 8 & 3 & 0 & 0.375 \\
2015 & 14 & 4 & 6 & 0.500 \\
2016 & 24 & 0 & 21 & 0.000 \\
\hline Total & 147 & 42 & 27 & 0.350 \\
\hline
\end{tabular}

Source: Authors' calculation based on data from the Public and Private Infrastructure Investment Management Center.

\section{GOVERNANCE ISSUES AFFECTING PUBLIC-PRIVATE PARTNERSHIP PROCESSES}

Good governance is needed for all phases of a PPP project's life cycle, and its lack at any one of these phases may result in a project failing. Figure 2 shows the major steps for the governance of PPPs at key project phases. The following section briefly looks at how governance issues affected a couple of highprofile infrastructure PPPs in the Republic of Korea at certain project phases.

Figure 2: Major Governance Issues for Public-Private Partnerships
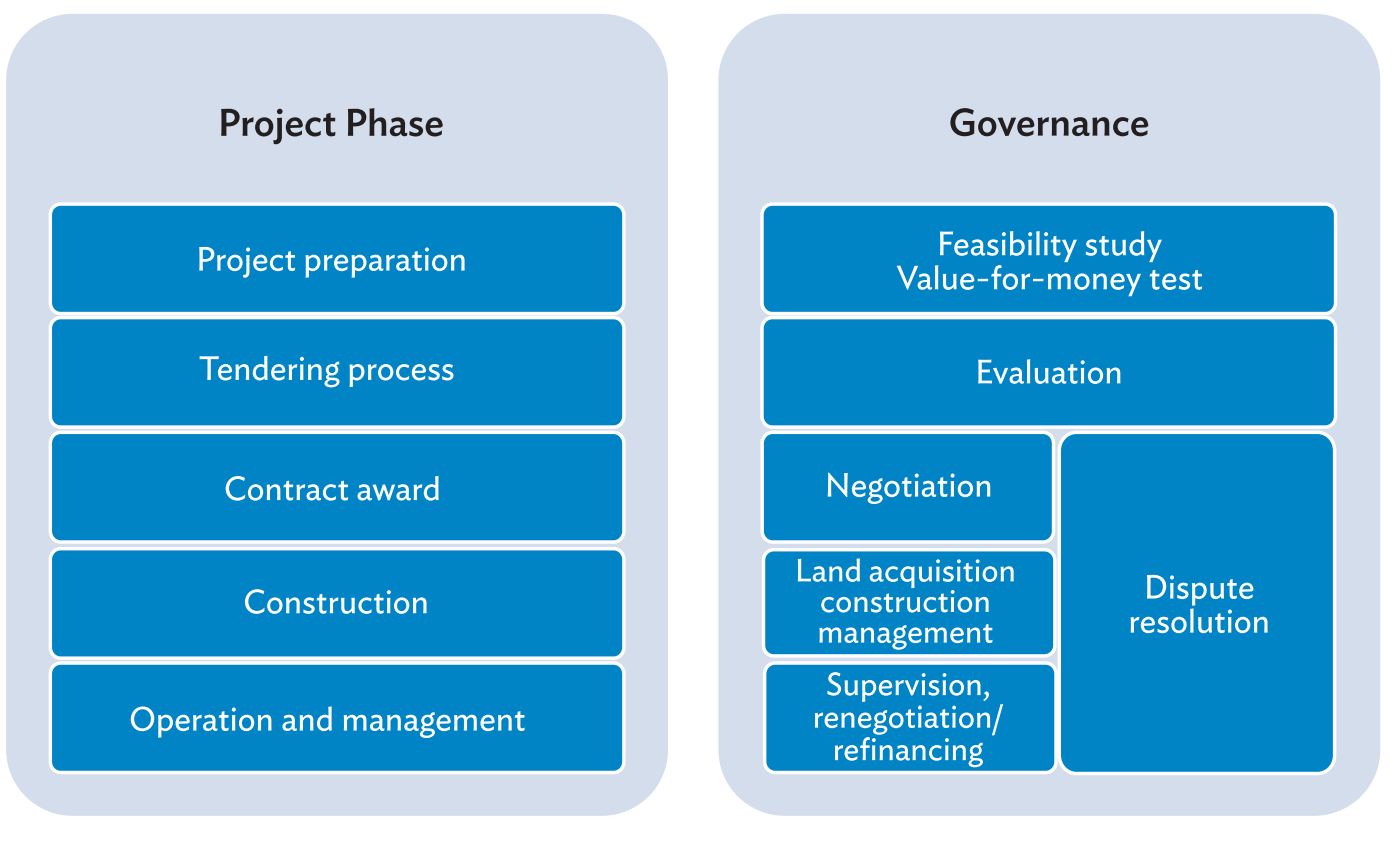

Source: Authors. 


\section{A. Project Preparation}

In preparing a PPP project, the public sector identifies and appraises candidate projects through, among other things, feasibility studies and value-for-money tests. A notable feature of the early years of PPPs in the Republic of Korea was the absence of these mechanisms and this has also affected some recent projects. Demand and revenue of the Incheon International Airport Railway Project, completed in 2007, was overestimated in the preparation phase because no value-for-money test was done. This case underscores the importance of having governance mechanisms in place at the pretender stage and having the capacity to implement them.

\section{B. Tendering and Contract Award}

PPPs require clear and transparent procurement measures, and independent experts who can appraise the value and quality of bids. And because PPP contracts are complex, managing PPP agreements requires a high level of expertise. Poorly defined project terms or an unqualified private partner can prolong negotiations before a contract award can be made or result in no agreement being reached. A case in point is the Hwado-Yangpyeong Expressway Project, which failed to reach final agreement after 8 months of negotiations because of concerns over the financial soundness of the private partner even though this party was selected as the preferred bidder. The lesson here is that the right criteria must be used to select a preferred bidder in a trustworthy procurement system. Assistance to build the capabilities to do this can be provided by legal and accounting professionals in the private sector or from multilateral development banks.

\section{Operation and Management: Settling Public-Private Partnership Disputes}

Because of the complexity of PPP projects and the way risk is allocated, disputes among stakeholders are frequent. KDI (2014), in a survey, found 69\% of PPP stakeholders in the Republic of Korea experienced disputes in the past and that these took a long time to resolve. Table 13 shows dispute resolution periods for PPPs in three infrastructure sectors.

Table 13: Average Dispute Resolution Periods for Public-Private Partnerships in the Republic of Korea, 2014

\begin{tabular}{|c|c|c|c|c|c|c|}
\hline Sector & $\begin{array}{l}\text { Under } 3 \\
\text { Months }\end{array}$ & 3-6 Months & 6-2 Months & 1-2 Years & 2 Years & Total \\
\hline Environment & 25.0 & 25.0 & 0.0 & 50.0 & 0.0 & 100.0 \\
\hline Road & 50.0 & 0.0 & 50.0 & 0.0 & 0.0 & 100.0 \\
\hline Harbor & 0.0 & 0.0 & 33.3 & 0.0 & 66.7 & 100.0 \\
\hline Total & 22.2 & 11.1 & 22.2 & 22.2 & 22.2 & 100.0 \\
\hline
\end{tabular}

Source: Korea Development Institute. 2015. Collection of Education Material for Public-Private Partnerships. Vol. 6. Sejong.

There are essentially four ways of resolving a PPP dispute-negotiation, mediation, arbitration, and court adjudication-and each has its own characteristics (Table 14). 
Table 14: Dispute Resolution Processes

\begin{tabular}{|c|c|c|c|c|}
\hline Feature & Negotiation & Mediation & Arbitration & Court Adjudication \\
\hline Voluntary/involuntary & Voluntary & Voluntary & Voluntary & Compulsory \\
\hline Third party engagement & No & Mediator & Agent & Judge \\
\hline Degree of formality & No restriction & No restriction & $\begin{array}{l}\text { By processes and } \\
\text { standards } \\
\text { determined by } \\
\text { consent among } \\
\text { involved parties }\end{array}$ & $\begin{array}{l}\text { Under legal } \\
\text { enforcement }\end{array}$ \\
\hline Nature of proceeding & $\begin{array}{l}\text { Unlimited } \\
\text { submission of } \\
\text { evidences }\end{array}$ & $\begin{array}{l}\text { Unlimited submission } \\
\text { of evidences }\end{array}$ & $\begin{array}{l}\text { Prove claim from } \\
\text { each party }\end{array}$ & $\begin{array}{l}\text { Prove claim from } \\
\text { each party }\end{array}$ \\
\hline Outcome & Consensus & Consensus & Award & Court ruling \\
\hline Binding & $\begin{array}{l}\text { Settlement by } \\
\text { contract }\end{array}$ & Settlement by contract & Executive force & Executive force \\
\hline Private/public process & Private & Private & $\begin{array}{l}\text { Private (and public } \\
\text { if needed) }\end{array}$ & Public \\
\hline
\end{tabular}

Source: Korea Development Institute. 2015. Collection of Education Material for Public-Private Partnerships. Vol. 6. Sejong.

Negotiation. This is the most common form of dispute resolution of the four methods. It has the benefit of costing less than the others, it can prevent sensitive information from getting out, and amicable relationships between PPP partners have a better chance of being maintained than in the other methods.

Mediation. Mediators use diverse techniques to help disputing parties find an optimal solution in a dispute, but they have no decision-making authority. For mediation to work, mediators must be seen by both parties as fair and neutral.

Arbitration. This is a method for resolving a dispute without going to court. Opposing parties refer their dispute for arbitration and agree to be bound by the arbitration decision, which is binding on the parties. An arbitration ruling impedes the right of access to court adjudication.

Court adjudication. This tends to incur considerable costs and time before a ruling is made, and-an additional drawback — a ruling can be made regardless of field of expertise.

PPP disputes have multiple causes, including how laws and regulations affecting partnerships are interpreted, financing arrangements, and which technologies are used in a project. Figure 3 shows that voluntary dispute resolution methods rather than going to court are preferred in the Republic of Korea when the amounts involved are relatively small. 
Figure 3: Performance of Public-Private Partnership Dispute Mediation in the Republic of Korea, 2012-2017

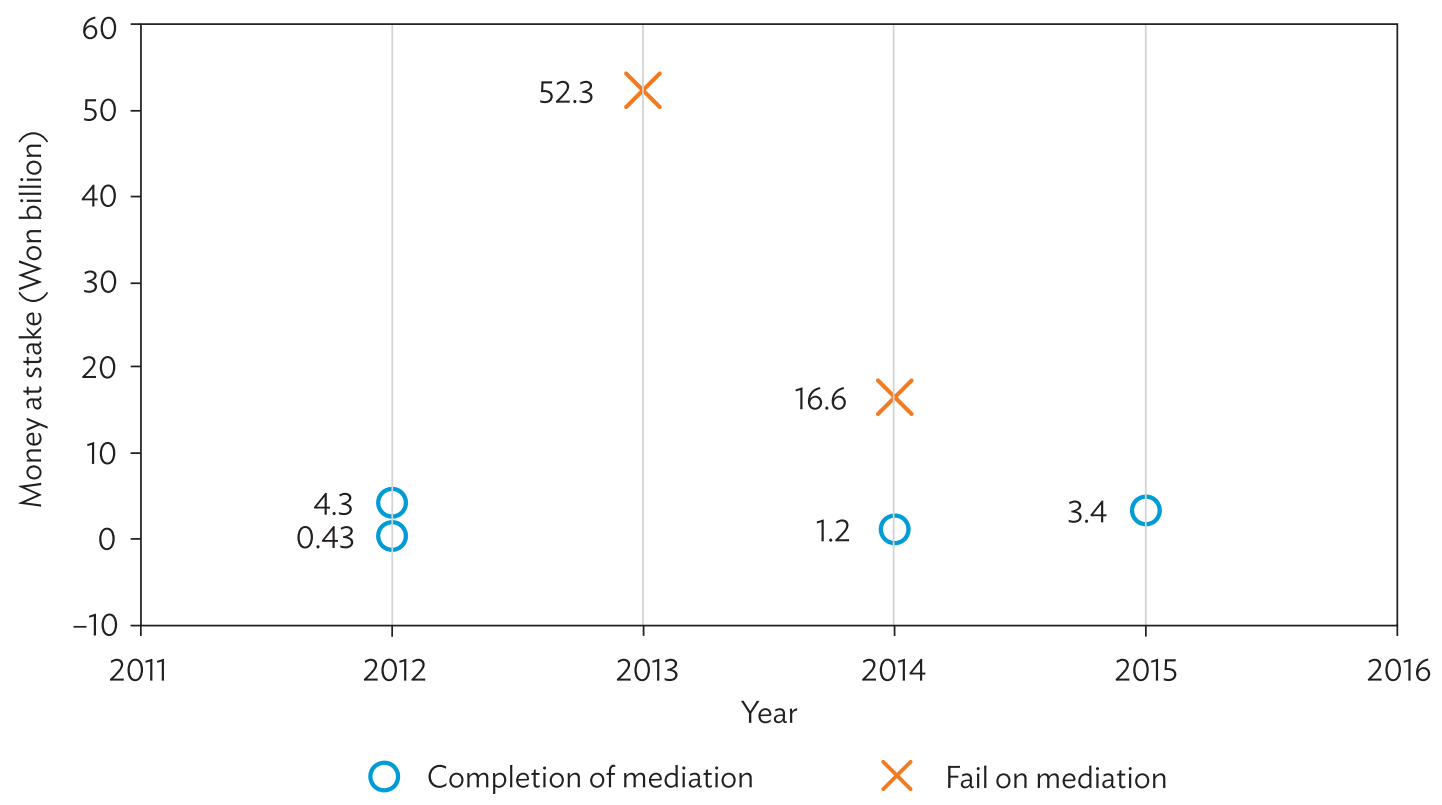

Source: Public and Private Infrastructure Investment Management Center.

The Republic of Korea's experience in resolving PPP disputes offers useful pointers for countries working to improve their dispute resolution methods. Because settlements in negotiation, mediation, and arbitration processes are not binding, PPP disputes tend not to be resolved through those channels in the Republic of Korea. Because a dispute between public and private sectors is basically a zero-sum game, it is seldom possible to satisfy both parties through these resolution methods. For negotiation and mediation, a consensus on how to solve a dispute is needed among the parties, but getting one is often difficult. For arbitration, an unsatisfied party can ignore the decision and opt to go to court to resolve the dispute. As a result, many PPP disputes in the Republic of Korea end up in court, although smaller disputes, as earlier noted, often get settled out of court using one of the other three methods. Since 2012, the Dispute Mediation Committee, which is under the Ministry of Strategy and Finance, has heard seven PPP cases, with four of them each involving less than W4.37 billion ( $\$ 4$ million) and being resolved outside court. 


\section{LEGAL AND INSTITUTIONAL FRAMEWORKS FOR PUBLIC-PRIVATE PARTNERSHIPS}

The Republic of Korea's effective legal and institutional frameworks, coupled with its well-developed financial markets, are recognized as the main drivers of the country's economic growth (Kim et al. 2011). The legal framework for PPPs was established by the Public-Private Partnerships in Infrastructure Act of 1994 to tackle a shortage of roads, railways, airports, and other infrastructure. The government at that time recognized the private sector had to be co-opted to help develop the country's infrastructure. The legal framework defines the eligible infrastructure for these partnerships, procurement types and processes, the roles of the parties, policy support, project implementation procedures, regulations for financing and refinancing projects, and risk management mechanisms. An important aspect of the institutional setting for PPPs is that the roles of government agencies involved in the procurement of these projects are clearly identified and set out in laws, regulations, and guidelines.

Strong legal frameworks and institutional settings are crucial to the success of PPPs and their ability to contribute to economic growth and social development. ${ }^{3}$ These make it easier to carry out complex and long-term projects, reduce transaction costs, ensure regulatory controls, and provide legal and economic mechanisms to resolve contract disputes. Most developing countries in Asia experience difficulties in implementing PPPs because of a lack of capacity to handle these types of projects in the public sector. Typical problems include (i) poor project selection and preparation, which deters investors; (ii) overlaps in newly introduced regulatory frameworks for PPPs with existing regulations, which also deal with construction of infrastructure facilities; (iii) implementation delays, especially in land acquisitions; (iv) the unfamiliarity of local governments with PPP mechanisms; and (v) lack of coordination between central and local governments on PPP projects.

Based on the Republic of Korea's experience, the following suggestions are offered to developing countries in Asia for tackling these problems. First, clear institutional frameworks for PPPs need to be set up. In many countries, numerous agencies play big roles in implementing PPP projects, but there is often a lack of coordination among them. Potential investors, for their part, prefer a onestop service covering all phases of a project's planning, construction, operations, and monitoring to reduce costs and time incurred by regulatory and administrative processes from numerous agencies handling PPPs. The solution is a dedicated public sector PPP unit. Both the Asia-Pacific Economic Cooperation and the Organisation for Economic Co-operation and Development underscore the importance of these units for establishing robust quantitative and qualitative methods to identify and assess potential PPP projects (APEC 2008, OECD 2010). In the Republic of Korea, the Public and Private Infrastructure Investment Management Center, an affiliated department of the KDI, conducts policy and strategy research on PPPs; provides technical support to the Ministry of Strategy and Finance Ministry, which develops and implements PPP policies; promotes PPP projects to foreign investors; and develops education programs on PPP systems.

Second, sound legal systems are needed for carrying out PPP projects. It is crucial to have a solid regulatory system in legal framework. It may be better to get a single piece of legislation-a PPP act - that covers all aspects of implementing and operating PPP projects, rather than this being fragmented and spread across various laws and regulations. PPP acts should specify the responsibilities

3 As the European Commission puts it, "It is essential for governments to develop clear legal and regulatory formats that identify the various steps in the process, together with rights and obligations of all involved" (European Commission 2003). 
of all key participants in a PPP and the rules for their participation. A sound legal framework for PPPs can provide stability during administration changes, which will boost the private sector's confidence in government PPP plans. PPP acts should specify the responsibilities of all key participants in a PPP and the rules for their participation.

While drawing up a legal framework for PPPs, detailed guidelines need to be legislated. In the Republic of Korea, these guidelines are set out in the Public-Private Partnerships in Infrastructure Act and the Public and Private Infrastructure Investment Management Center's 13 guidelines that cover sectors and PPP methods. These include guidelines on conducting feasibility tests on BTO and BTL projects, refinancing projects, and for the environmental sector and road infrastructure. Transparency, objectivity, and consistency are vital in the formulation of these guidelines, which can be used for the entire life cycle of a PPP project. These guidelines are especially important for giving private investors a clear understanding of their responsibilities as partners in government projects. Beyond their current application, these guidelines could also cover value for money, drawing up requests for project proposals, output specifications, and tender evaluations.

Third, government guarantees to provide private partners with appropriate profits and to share risks can be effective in getting PPP projects off the ground. Revenue guarantees sweeten the risk sharing and have proved to be effective in attracting private partners. But long-term revenue guarantees carry fiscal risks and need to be set cautiously. In the Republic of Korea, transport PPP projects largely relied on minimum revenue guarantees, but these became a heavy fiscal burden and were aggravated by overly optimistic demand forecasts. These guarantees were dropped for PPPs in 2009 , leaving, in 2011, guarantees totaling W3.15 trillion ( $\$ 2.9$ billion) for 36 PPP projects. When the scheme was ended, private sector participation in transport infrastructure significantly declined.

\section{CONCLUSION}

The Republic of Korea's experience in PPPs has largely been a success story. The use of PPPs for infrastructure since mid-1990s has delivered significant positive economic and social benefits through the channels of capital inflows, increasing social welfare benefits and better delivery of services, and reducing fiscal burdens through better value for money. That said, there have been bumps along the way, such as the impact on transport PPPs from scrapping government minimum revenue guarantees, as discussed earlier.

As a fiscal stimulus measure, PPPs have been shown to have had only a limited effect. Many countries, including France, the Republic of Korea, and Thailand, promoted PPPs for fiscal stimulus to help recover from the 2008 global financial crisis. But research shows this can crowd out public investment, and because PPP investments tend to just replace government spending, they offer very little-if any-fiscal stimulus.

The Republic of Korea's experience with PPPs highlights several challenges in using this financing modality for infrastructure. Because supporting private investment in infrastructure requires the government to borrow money from future budgets, PPPs are inevitably a challenge for fiscal management. There is also an inherent tension in PPP agendas. The Republic of Korea initially put a high priority on promoting a PPP market, but later shifted its focus to fiscal discipline-and the government is having a hard time reinvigorating the PPP market. 
Another challenge has been setting tariffs on PPP infrastructure projects. Tariffs for transport infrastructure, for example, tend to be higher for government-funded transport projects than in other sectors, since there needs to be sufficient incentives for the private sector to get involved. Users may bear a bigger share of a transport project's life-cycle cost than for purely government-funded infrastructure projects.

And at the end of the day, PPPs are not a must-have solution but an option for building and upgrading infrastructure. The reason they are being promoted is because they can mobilize needed resources from the private sector, maximize value for money, bring creativity and efficiency to a project, and be a source of fiscal stimulus. That said, countries should be clear on why they are promoting the PPP modality for infrastructure. 


\section{REFERENCES}

Asia-Pacific Economic Cooperation (APEC). 2008. "Joint Ministerial Statement. 15th Finance Ministers' Meeting." Peru.

Asian Development Bank (ADB) and Korea Development Institute (KDI). 2011. Public-Private Partnership Infrastructure Projects: Case Studies from the Republic of Korea. Manila/Seoul.

Campos, Javier, Antonio Estache, Noelia Martin, and Lourdes Trujillo. 2003. Macroeconomic Effects of Private Sector Participation in Infrastructure. Washington, DC: World Bank.

European Commission. 2003. Guidelines for Successful Public-Private Partnerships. Brussels.

Eurostat. 2009. “New Developments in PPPs.” Financial Accounts Working Group. Luxembourg.

Hodges, John T., and Georgina Dellacha. 2007. "Unsolicited Infrastructure Proposals: How Some Countries Introduce Competition and Transparency." PPIAF Working Paper No. 1. Nairobi: Public-Private Infrastructure Advisory Facility.

Kim, Jay-Hyung, Jungwook Kim, Sunghwan Shin, and Seung-Yeon Lee. 2011. Public-Private Partnership Infrastructure Projects: Case Studies from the Republic of Korea. Seoul: KDI.

Korea Development Institute (KDI). 2014. Comprehensive Evaluation on Public-Private Partnership Projects in Korea. Sejong.

—. 2015. Collection of Education Material for Public-Private Partnership. Vol. 6. Sejong.

Lee, Hangyong, and Chang-Yong Rhee. 2007. Private Participation in Infrastructure and Macroeconomy: The Experience of Korea. Seoul: KDI.

McDonald, Mott. 2002. Review of Large Public Procurement in the UK: The Mott McDonald Report. Sydney: Infrastructure Australia.

Organisation for Economic Co-operation and Development (OECD). 2010. Dedicated Public-Private Partnership Units. Paris. 


\section{Rationale and Institution for Public-Private Partnerships}

Public-private partnerships (PPPs) can deliver significant economic benefits, but only if they are well executed with strong legal, regulatory, and institutional frameworks. This paper examines the factors that have been important for shaping the PPP landscape of the Republic of Korea. Topics covered include fiscal soundness, unsolicited project proposals, and the refinancing and renegotiation of PPPs. It also explores the economic and social welfare benefits of infrastructure PPPs and highlights lessons learned from various countries in Asia.

\section{About the Asian Development Bank}

ADB is committed to achieving a prosperous, inclusive, resilient, and sustainable Asia and the Pacific, while sustaining its efforts to eradicate extreme poverty. Established in 1966, it is owned by 67 members48 from the region. Its main instruments for helping its developing member countries are policy dialogue, loans, equity investments, guarantees, grants, and technical assistance. 